\title{
Spatial dynamics of orange production in the state of Paraná, Brazil
}

\author{
Gustavo Vaz da Costa ${ }^{1}$, Carmen Silvia Vieira Janeiro Neves ${ }^{2}$, Tiago Santos Telles ${ }^{3}$
}

\begin{abstract}
The aim of this study was to identify and qualify the microregions specialized in orange production and the spatial dynamics of citrus production in the state of Paraná, Brazil. For this purpose, data from the Brazilian Institute of Geography and Statistics and the Brazilian Central Bank were used. The location quotient (LQ) methodology was applied, the principal component analysis (PCA) and the cluster analysis were carried out, and information regarding the location of industries and agribusiness cooperatives that process orange juice in the state of Paraná was collected. The LQ results, subdivided into 5-year periods, denote changes in the spatial dynamics of orange production. Between 1998-2002 and 2013-2017, the specialized microregions increased from nine to 11; in addition, the consolidation of a citrus belt, which extended from the northwestern to the northeast area of Paraná, took place. Two main components explained $89.16 \%$ of the total data variability and four clusters were identified. The microregion of Paranavaí was the most specialized and the most important for the orange production chain in Paraná. The dynamics of orange production were spatially associated with the location of industries and agribusiness cooperatives in the sector, which were concentrated in the northwestern and mid-northern Paraná. Indexing terms: fruit, citrus, regional specialization, production chain.
\end{abstract}

\section{Dinâmica espacial da produção de laranja no Paraná}

Corresponding author: telles@iapar.br

Received: July 11, 2019 Accepted: January 14, 2020

Copyright: All the contents of this journal, except where otherwise noted, is licensed under a Creative Commons Attribution License.

\section{(cc) $\mathbf{E Y}$}

Resumo - O estudo teve por objetivo identificar e qualificar as microrregiões especializadas na produção de laranja e a dinâmica espacial da citricultura no estado do Paraná. Para tanto, foram utilizados dados do Instituto Brasileiro de Geografia e Estatística e do Banco Central do Brasil. Foi aplicada a metodologia do quociente locacional (QL), realizada a análise de componentes principais (ACP), efetuada a análise de agrupamentos (cluster) e coletadas informações relativas à localização das industriais e cooperativas agroindustriais de transformação de suco de laranja no Paraná. Os resultados do QL, subdivididos em períodos de 5 anos, denotam mudanças na dinâmica espacial na produção de laranja. Entre os períodos de 1998-2002 e 2013-2017 houve um aumento de 9 para 11 microrregiões especializadas, além da consolidação de um cinturão citrícola, que se estende do Noroeste ao Norte Pioneiro do Paraná. Foram identificados dois componentes principais que explicaram $89,16 \%$ da variabilidade total dos dados, além de serem definidos quatro clusters. A microrregião de Paranavaí foi a mais especializada e de maior importância para cadeia produtiva de laranja do Paraná. A dinâmica espacial da produção de laranja se mostrou espacialmente associada à localização de cooperativas e agroindústrias do setor, que se concentram no Noroeste e no Norte Central do Paraná.

Termos para indexação: fruticultura, citricultura, especialização regional, cadeia produtiva. 


\section{Introduction}

The citrus production chain plays an important role in the Brazilian economy; it generates 230,000 jobs and approximately US $\$ 15$ billion per year (NEVES; KALAKI, 2015). In addition, the Brazilian citrus production plays an important role in the global citrus production; it accounts for about $37 \%$ of the global orange production [Citrus sinensis (L.) Osbeck] and for $64 \%$ of the global orange juice production (USDA, 2019).

Since the 1960s, the dynamics of the Brazilian citrus sector have been based on the export of frozen concentrated orange juice; therefore, citrus production is primarily determined by the demand for frozen concentrated orange juice and not aimed at fresh citrus consumption. According to data from the Brazilian Institute of Geography and Statistics - IBGE (2019), in 2018 the largest planted area in the country (377,000 ha), producing around 12.9 million tonnes of oranges, with an average productivity of $34.2 \mathrm{tha}^{-1}$, was in the state of São Paulo, which is Brazil's main orange producer. In the same year, the state of Paraná, the third largest orange producer in the country, produced approximately 835,000 t of fruits in 22,500 ha, with an average productivity of $37.1 \mathrm{tha}^{-1}$ (IBGE, 2019).

It is worth mentioning that it was only in the late 1980s that citriculture became an economic option in Paraná, supported by research results from the Agronomic Institute of Paraná (IAPAR). The implantation of citrus in Paraná started in the Alto Ribeira region with the production of tangerines and began to consolidate in the late 1980s with the production of oranges in the northwestern region (IAPAR, 1987; AULER et al., 2008; TAZIMA et al., 2010). However, it was in the 1990s when the integrated management for the prevention of citrus canker, proposed by IAPAR, took place, that a more expressive expansion of the citrus activity was observed in Paraná (TAZIMA et al., 2009), establishing orange as the main product of Paraná's citrus production. In this perspective, it has been hypothesized that after the constitution of a technological model for the management and cultivation of citrus fruits in Paraná, developed by IAPAR, regions specialized in orange production, concentrated in the northwestern and northern regions of the state, were consolidated, establishing its citrus production chain. In addition, citrus producing regions have entered the market differently, with an organizational pattern in the production chain in which there is a strong relationship between the producer and the industry (SABES; SOUZA FILHO, 2010), thus establishing the hypothesis that orange production in Paraná is spatially concentrated around industrial plants of the citrus sector.

Despite the importance of citrus production for agribusiness in Paraná, owing to its relatively recent implementation in the state, information regarding the spatial distribution of the main orange producing regions, the techno-economic production indicators, and the technological standards used by citrus growers is still incipient. Thus, understanding the particularities of orange production as well as its territorial organization is of great importance in identifying territorial transformations in citrus production and the displacement of citrus cultures in rural areas; this understanding will enable us to identify the main vectors of spatial mobility, whether they are linked to natural, political, or socioeconomic conditions. The spatial analysis results are fundamental for the planning of contemporary agriculture through knowledge about the regional concentration of production and the development of the production chain, especially for the agroindustrial segment, with emphasis on agribusiness cooperatives. In this context, the aim of this study was to identify and qualify the microregions specialized in orange production, to analyze the territorial dynamics of citrus cultures, and to examine the consolidation of the citrus chain in the state of Paraná.

\section{Materials and methods}

The data used in the survey referring to the harvested area (ha), amount produced ( $\mathrm{t})$, and productivity $\left(\mathrm{t} \mathrm{ha}{ }^{-1}\right)$ were extracted from the Municipal Agricultural Survey - PAM (IBGE, 2019) and the data concerning rural credit were obtained from the Brazilian Central Bank - BCB (2019) and cover the years 1998-2017. The analyses included the 39 microregions of Paraná, which were defined by IBGE. The information considered for each microregion had to do with average orange productivity, average gross production value (GPV), and location quotient (LQ).

LQ is a measure of relative regional specialization, which aims to compare certain activities based on a basic aggregate (FRACASSO; MARZETTI, 2017). In this study, LQ was used to identify microregions specialized in orange production. This indicator has been used for the same purpose in relation to different agricultural activities, with emphasis on soy (FREITAS; MENDONÇA, 2016), coffee (VOLSI et al., 2019), and dairy cattle (MARION FILHO et al., 2015; TELLES et al., 2017). To reduce the possible effects generated by seasonality in orange production, the average GPV was used to calculate the LQ for the 1998-2002, 2003-2007, 2008-2012, and 2013-2017 periods ${ }^{1}$. The LQ was obtained from the ratio of the GPV of the orange crop and the GPV of agriculture, adopting Equation 1 proposed by Isserman (1977):

\footnotetext{
1 These same periods were used to analyze the harvested area (ha), amount produced $(\mathrm{t})$, and productivity $\left(\mathrm{t} \mathrm{ha}^{-1}\right)$, in order to reduce possible effects generated by seasonality in orange production.
} 


$$
Q L=\frac{\frac{E_{j}^{i}}{E_{j}}}{\frac{E^{i}}{E}}
$$

In this case: $\mathrm{E}_{j}^{\mathrm{i}}$ is the GPV of the orange crop $(i)$ in region $j$; $\mathrm{E}^{\mathrm{i}}$ is the GPV of agriculture in region $j$; $\mathrm{E}^{\mathrm{i}}$ is the sum of the GPV of the orange crops ( $i$ ) of all regions; $E$ is the sum of the GPV of agriculture in all regions. Microregions considered specialized in citrus production had an LQ $\geq$ 1 and those not specialized in citrus production had an $\mathrm{LQ}<1$.

After defining the microregions of Paraná that were specialized in orange production, principal component analysis (PCA) was carried out. For this, the following variables linked to orange production were used: (i) number of contracts and credit volume (in US\$) of the National Program for Strengthening Family Agriculture (PRONAF); (ii) number of contracts and credit volume (in US\$) of the National Program to Support Medium-sized Rural Producers (PRONAMP); (iii) number of contracts and credit volume (in US\$) for financing not linked to a specific program (SV); (iv) productivity (in $\mathrm{t} \mathrm{ha}^{-1}$ ); (v) number of industrial plants ${ }^{2}$; (vi) specialized microregions (determined by the LQ). PCA was applied to specialized microregions in order to capture the unique characteristics of each, which cannot be achieved by the LQ analysis.

Based on the PCA results, a cluster analysis of the microregions was performed to obtain homogeneous groups based on the degree of similarity between them and the Euclidean distance, according to Ward's method (VOLSI et al., 2019).

All nominal prices were corrected to real prices. The amounts in R \$ were updated to the December 2019 prices, based on the Extended National Consumer Price Index (IPCA) ${ }^{3}$ from IBGE. The real prices were also converted to US\$ Dollars, based on the exchange rate of December 2019. The SPSS 21 software was used to process data and ArcGIS 10.3.1 was used to elaborate maps.

\section{Results and discussion}

The orange area harvested in the state of Paraná in 1998 was 11,500 ha, while in 2017 it was approximately 24,000 ha, that is, in a period of about 20 years, a 109 $\%$ increase in the area intended for the production of this crop was observed (Figure 1). The state of Paraná produced approximately 255,000 t of oranges in 1998 and approximately $871,000 \mathrm{t}$ in 2017 , which corresponded to a $242 \%$ increase; these results are indicative of productivity

2 The survey of the number and location of industrial plants and agroindustrial orange juice processing cooperatives in Paraná was carried out in December 2018.

3 The IPCA was used because it is the official inflation index in Brazil. gains. In 1998, 22 orange $t \mathrm{th}^{-1}$ were produced, while in 2017, 36 orange $t$ ha $^{-1}$ were produced; this corresponded to a $64 \%$ increase. Among the factors responsible for the increase in the orange production and the improvement of the productivity indicators in the state of Paraná, public research, development, technological innovations, and knowledge transfer stand out (GASQUES, 2017; VIEIRA FILHO, 2018).

The orange production area had a more accelerated growth from 2008 to 2014 than it did from 1998 to 2007 (Figure 1). In the case of the harvested area, this increase was related to the establishment of fruit processing industries aiming at the production of juice, especially in the northern and northwestern Paraná, the favorable soil and climate conditions for citrus production, the strong organization of citrus growers in cooperatives or associations, technical assistance, support for agricultural research and defense (AULER et al., 2014), prices reached by producers in the last harvests, and the growth potential of domestic and foreign markets (TAZIMA et al., 2008). Among the factors that have contributed to the improvement of orange production and productivity, the following stood out: more intensive use of inputs such as agricultural machines, implements, fertilizers, and pesticides; an improvement in the quality of genetic material, which enabled different species and varieties to adapt to the growing environment (MODA-CIRINO et al., 2012); management improvements (LEITE JUNIOR; MOHAN; 1990; VARGAS et al., 2013), with emphasis on the densification of orchards, which is one of the practices for the control of diseases such as Huanglongbing (FUKUDA et al., 2010; MOREIRA et al., 2019). The harvested area and production increases were noted in advance by rural credit financing to finance production. From 2013, an increase in the number of contracts and total rural credit value granted by the program was observed (Figure 2).

An increase in the number of contracts between 2002 and 2010 was observed (Figure 2a). From 2010 onward, the number of contracts started to decline to the point that in 2017 only 211 contracts were signed, which was less than the number of contracts that had been signed since 2005. From 2013 on ward, we analyzed the number of contracts per type of rural credit program, which enabled us to profile the producers based on their ability to receive financing from programs such as PRONAF and PRONAMP. There appeared to be a distribution in the number of contracts, which did not show a concentration in relation to the producer's profile as it was independent of the producer's status - family producer (PRONAF), medium-sized producer (PRONAMP), or large producer (CSV).

Between 2002 and 2013, there was a significant increase in the amount of rural credit values granted to fund orange production in the state of Paraná, as is shown 


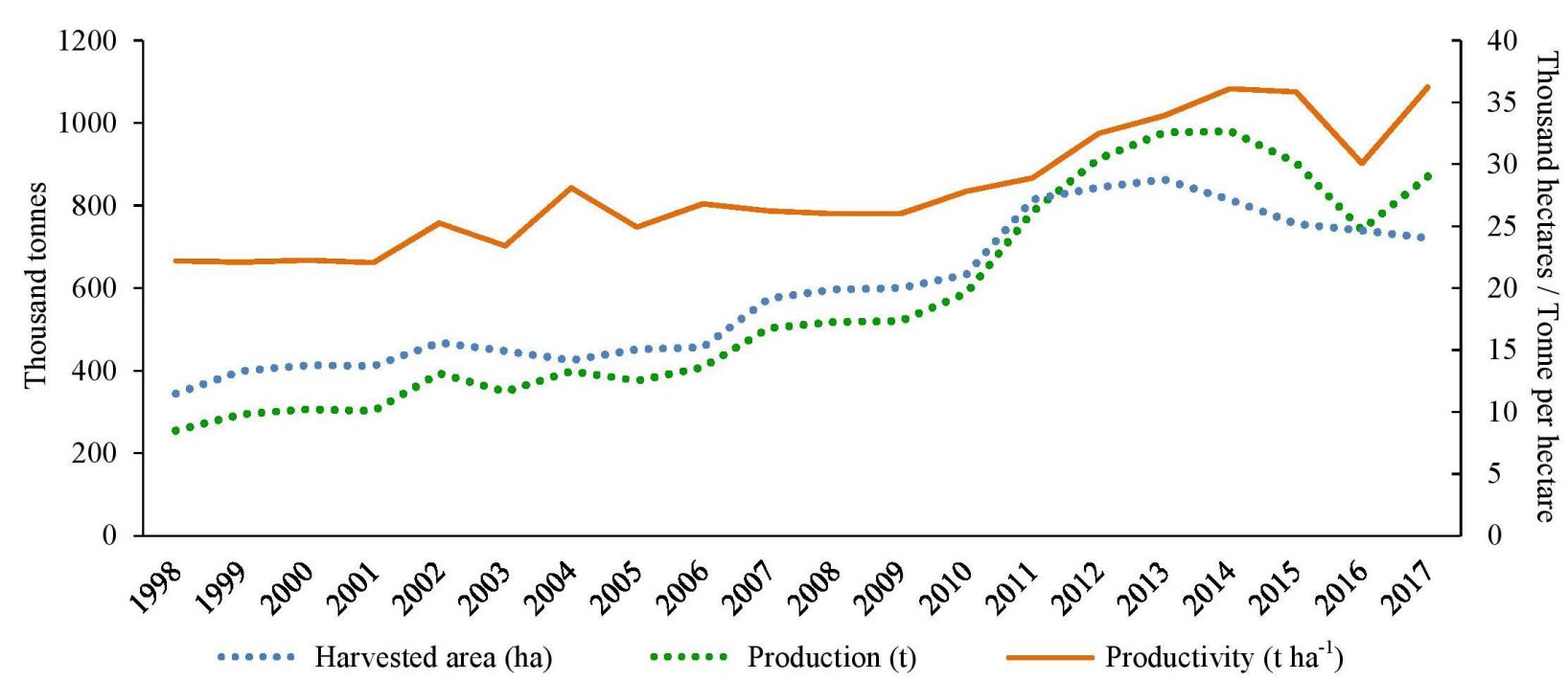

Figure 1. Evolution of the harvested area, production, and productivity orange in the state of Paraná, from 1998 to 2017. Source: data from the Municipal Agricultural Production (PAM) from the Brazilian Institute of Geography and Statistics (IBGE).

(A)

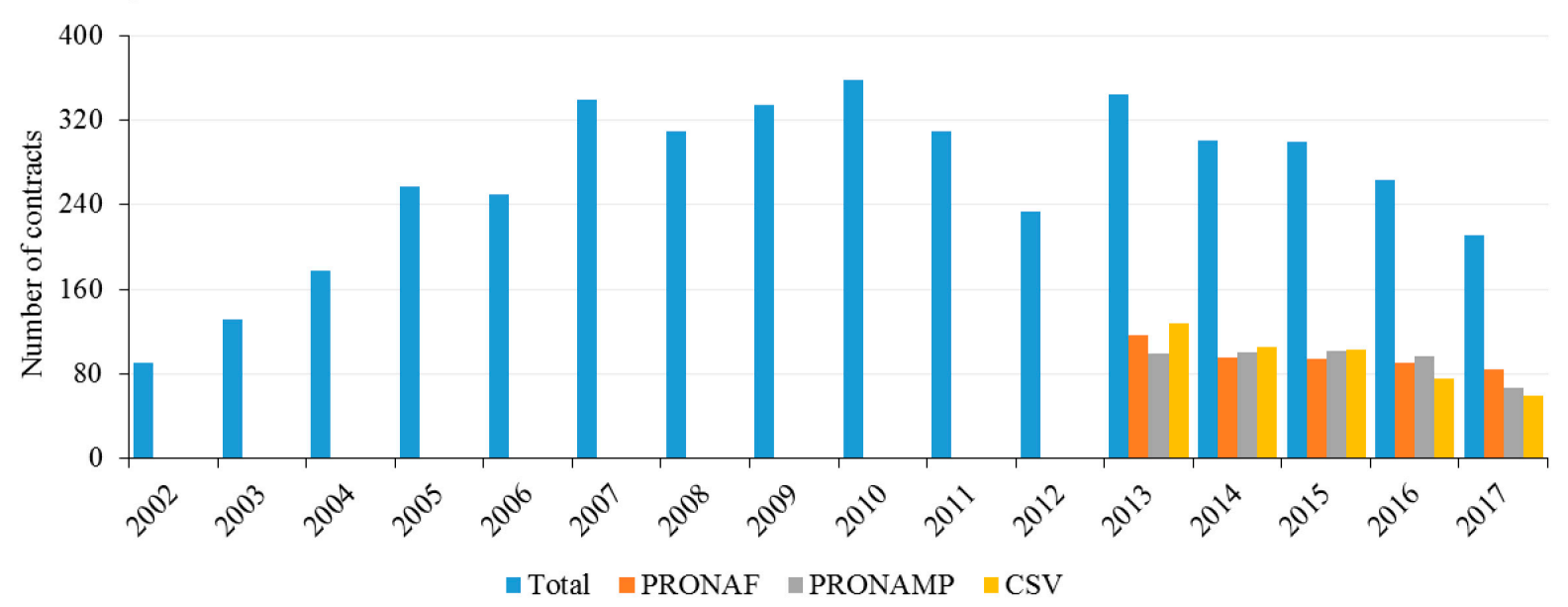

(B)

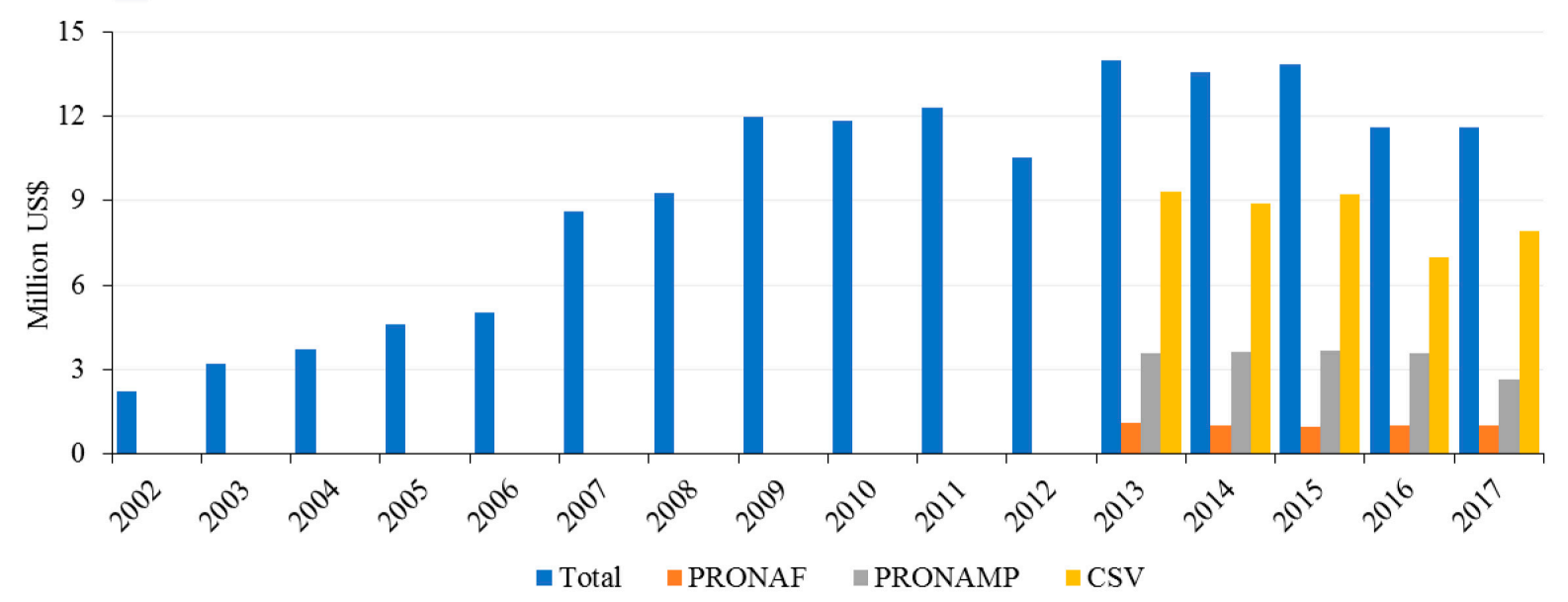

Figure 2. Number of (A) contracts and (B) rural credit values granted to finance the orange production cost in the state of Paraná from 2002 to 2017.

Source: the rural credit data matrix (MDCR) of the Brazilian Central Bank (BCB).Notes: PRONAF: National Program for Strengthening Family Farming. PRONAMP: National Program to Support Medium-sized Rural Producers. CSV: financing not linked to a specific program. 
in Figure 2b. In 2002 and in 2003 approximately R \$8.7 and $\mathrm{R} \$ 54$ million rural credits, respectively, were available. The amounts granted were concentrated in the CSV (the program that accounted for about $65.5 \%$ of the total rural credit), followed by PRONAMP (26.5\% of the total), and PRONAF ( $8 \%$ of the total).

The microregions of Paraná specialized in orange production were Paranavaí, Umuarama, Cianorte, Astorga, Porecatu, Floraí, Apucarana, Londrina, Assaí, Cornélio
Procópio, Capanema, Francisco Beltrão, Cerro Azul, and Paranaguá (Figure 3). The microregion of Paranavaí stood out as having the largest planted area, production, productivity, and LQ, showing high specialization in orange production. It is noteworthy that in the 2013-2017, 5 -year period the microregion of Paranavaí accounted for $41.3 \%$ of the harvested area and for $50.7 \%$ of the amount of oranges produced in the state of Paraná.
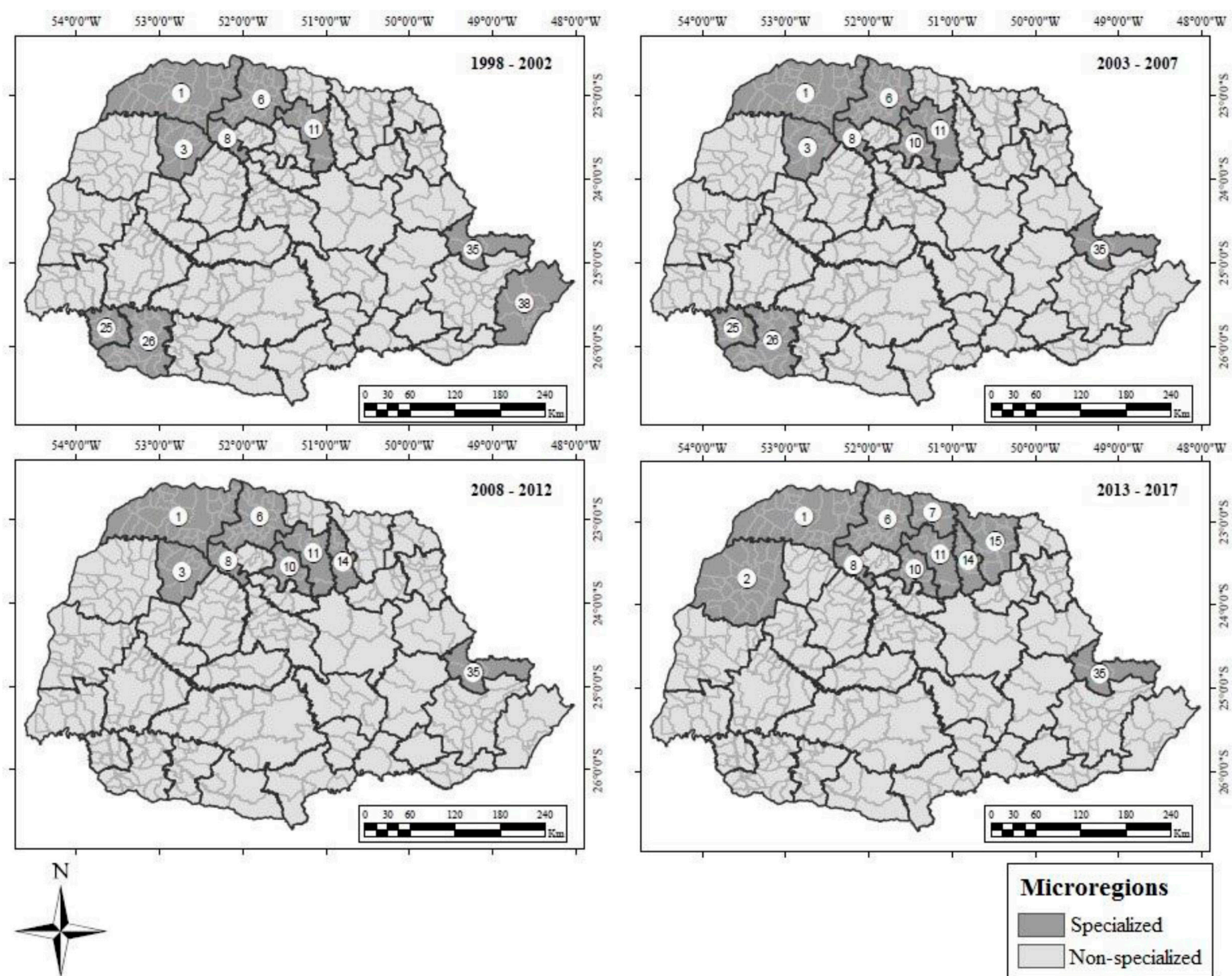

Figure 3. Microregions of the state of Paraná specialized in orange production in the 1998-2002, 2003-2007, 20082012, and 2013-2017 periods.

Notes: 01: Paranavaí. 02: Umuarama. 03: Cianorte. 06: Astorga. 07: Porecatu. 08: Floraí. 10: Apucarana. 11: Londrina. 14: Assaí. 15: Cornélio Procópio. 25: Capanema. 26: Francisco Beltrão. 35: Cerro Azul. 38: Paranaguá.

From 1998 to 2002, nine microregions were specialized in orange production in Paraná: Paranavaí, Cianorte, Astorga, Floraí, Londrina, Capanema, Francisco Beltrão, Cerro Azul, and Paranaguá (Figure 3). Between 2003 and 2007, nine microregions remained specialized, but with the following change: Apucarana became specialized, while Paranaguá ceased to be. In the period from 2008 to 2012, the number of specialized microregions was reduced to eight, with Assaí becoming specialized and Francisco Beltrão and Capanema no longer being specialized. In the period from 2013 to 2017, 10 microregions were specialized; Umuarama, Porecatu, and Cornélio Procópio became specialized, while Cianorte ceased to be. Thus, there was a production concentration and microregions specialized in orange production were located in the northwestern and northern regions of the state of Paraná. The reasons why some microregions were no longer specialized are diverse; the main reason was that some regions already had a low specialization level, a situation that was intensified by the increase in the cultivation of other products. In the case of Paranaguá, there was an increase in the production of rice and heart of palm. In the case of Capanema and Francisco Beltrão, there was an increase in the production of soybean crops (IBGE, 2019). 
It was evident how the LQ increased relative to the other variables presented (Table 1) because the LQ was determined based on the GPV, which was directly or indirectly related to the other variables. This demonstrates that a large production does not necessary classify a microregion as specialized, as was the case of Paranaguá in the first period. It also demonstrates the sensitivity of the LQ regarding the Cerro Azul microregion, which varied over the periods examined. Additionally, it shows how the method is able to identify regions that stand out from the others, as in the case of Paranavai the production of which accounted for approximately $50.6 \%$ of Paraná's total orange production in the last analyzed period and, therefore, obtained an LQ of 11.98.

Table 1. Harvested area, production, productivity, and location quotient of microregions specialized in orange production in the state of Paraná by averages from 1998 to 2017.

\begin{tabular}{|c|c|c|c|c|c|c|c|c|}
\hline \multirow[t]{2}{*}{ FU/microregions } & 1998-2002 & 2003-2007 & 2008-2012 & 2013-2017 & 1998-2002 & 2003-2007 & 2008-2012 & 2013-2017 \\
\hline & \multicolumn{4}{|c|}{ Harvested area (ha) } & \multicolumn{4}{|c|}{ Amount produced (t) } \\
\hline Paraná & 13,568 & 15,704 & 23,255 & 25,956 & 310,146 & 406,709 & 664,579 & 894,294 \\
\hline Paranavaí & 4,699 & 5,677 & 9,079 & 10,721 & 112,708 & 173,621 & 319,730 & 452,941 \\
\hline Umuarama & 321 & 377 & 586 & 1,512 & 6,707 & 7,413 & 10,963 & 43,991 \\
\hline Cianorte & 410 & 567 & 883 & 851 & 8,687 & 15,044 & 23,930 & 28,093 \\
\hline Astorga & 1,260 & 1,603 & 2,988 & 3,393 & 42,662 & 46,389 & 98,564 & 123,245 \\
\hline Porecatu & 173 & 239 & 549 & 678 & 3,579 & 5,450 & 12,755 & 15,970 \\
\hline Floraí & 625 & 902 & 1,637 & 1,403 & 22,888 & 30,345 & 51,136 & 51,266 \\
\hline Apucarana & 369 & 526 & 676 & 742 & 4,776 & 11,211 & 15,685 & 21,154 \\
\hline Londrina & 1,175 & 1,830 & 2,733 & 2,120 & 19,042 & 38,839 & 59,720 & 69,884 \\
\hline Assaí & 62 & 119 & 531 & 1,079 & 964 & 1,882 & 8,638 & 21,582 \\
\hline Cornélio Procópio & 69 & 130 & 481 & 826 & 823 & 2,159 & 7,885 & 17,605 \\
\hline Capanema & 298 & 201 & 261 & 209 & 7,558 & 5,722 & 7,781 & 5,815 \\
\hline Francisco Beltrão & 948 & 645 & 394 & 320 & 27,186 & 17,097 & 10,220 & 7,964 \\
\hline Cerro Azul & 1,287 & 1,254 & 976 & 579 & 26,361 & 23,916 & 14,214 & 8,506 \\
\hline \multirow[t]{2}{*}{ Paranaguá } & 85 & 78 & 24 & 15 & 1,030 & 676 & 360 & 232 \\
\hline & \multicolumn{4}{|c|}{ Productivity (t ha' $\left.{ }^{-1}\right)$} & \multicolumn{4}{|c|}{ Location quotient } \\
\hline Paraná & 23 & 26 & 29 & 34 & - & - & - & - \\
\hline Paranavaí & 24 & 31 & 35 & 42 & 13.05 & 12.45 & 12.25 & 11.98 \\
\hline Umuarama & 21 & 20 & 19 & 29 & 0.81 & 0.67 & 0.57 & 1.09 \\
\hline Cianorte & 21 & 27 & 27 & 33 & 1.33 & 1.70 & 1.50 & 0.95 \\
\hline Astorga & 34 & 29 & 33 & 36 & 4.58 & 3.33 & 4.67 & 4.13 \\
\hline Porecatu & 21 & 23 & 23 & 24 & 0.65 & 0.72 & - & 1.47 \\
\hline Floraí & 37 & 34 & 31 & 37 & 3.56 & 3.53 & 4.65 & 2.34 \\
\hline Apucarana & 13 & 21 & 23 & 29 & 0.88 & 1.56 & 1.01 & 1.23 \\
\hline Londrina & 16 & 21 & 22 & 33 & 2.11 & 3.71 & 3.00 & 4.21 \\
\hline Assaí & 15 & 16 & 16 & 20 & 0.20 & 0.37 & 1.05 & 3.25 \\
\hline Cornélio Procópio & 12 & 17 & 16 & 21 & 0.06 & 0.22 & 0.48 & 1.31 \\
\hline Capanema & 25 & 28 & 30 & 28 & 1.24 & 1.12 & 0.93 & 0.66 \\
\hline Francisco Beltrão & 29 & 26 & 26 & 25 & 2.78 & 1.31 & 0.53 & 0.52 \\
\hline Cerro Azul & 20 & 19 & 15 & 15 & 6.72 & 12.19 & 2.90 & 2.34 \\
\hline Paranaguá & 12 & 9 & 15 & 15 & 1.01 & - & - & 0.13 \\
\hline
\end{tabular}

Source: data from the Municipal Agricultural Production (PAM) from the Brazilian Institute of Geography and Statistics (IBGE). 
Table 2.Components of linear combinations of principal component analysis (PCA).

\begin{tabular}{lcc}
\hline \multirow{2}{*}{ Variables } & \multicolumn{2}{c}{ Components } \\
\cline { 2 - 3 } & Technified production & Family production \\
\hline LQ & 0.955 & -0.051 \\
Industry/Cooperatives & 0.936 & 0.303 \\
Productivity & 0.727 & -0.542 \\
PRONAF & 0.543 & 0.779 \\
PRONAMP & 0.849 & -0.391 \\
CSV & 0.930 & 0.073 \\
\hline
\end{tabular}

Notes: LQ: location quotient. PRONAF: National Program for Strengthening Family Farming. PRONAMP: National Program to Support Medium

Table 2 shows the PCA components determined by the largest accumulated variation. Based on the PCA, the formation of two principal components was verified and named after load values. Component 1 was explained by the LQ (0.955), existence of industrial orange juice processing plants $(0.936)$, productivity (0.727), PRONAMP (0.849), and CSV (0.930) variables and was named technical or technified production, mainly because it was linked to variables associated with production indicators. In turn, Component 2 was explained by the PRONAF (0.779) variable and was named family production, as it was linked to credit aimed at family farmers. The first two principal components together accounted for $89.16 \%$ of the total data variability. Component 1 and Component 2 explained 69.94\% and $19.22 \%$ of the total data variability, respectively (Figure $4)$.

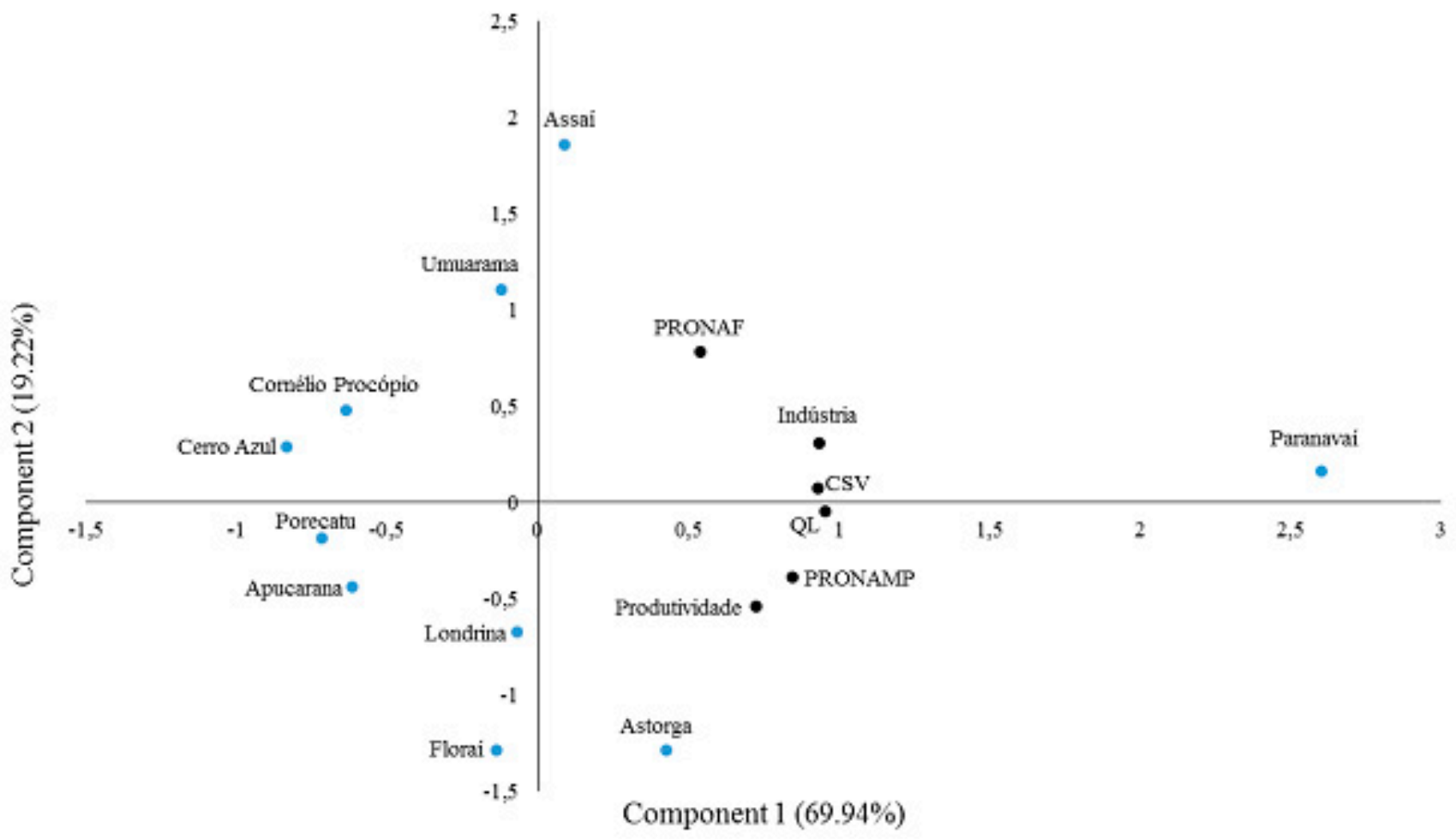

Figure 4. Principal component analysis of the microregions specialized in orange production in the state of Paraná; average data from 2013 to 2017.

Notes: PRONAF: National Program for Strengthening Family Farming. PRONAMP: National Program to Support Medium-sized Rural Producers. CSV: Financing not linked to a specific program. LQ: location quotient. 
From the cluster analysis of the microregions specialized in orange production in the state of Paraná in the 2013-2017 period, four groups were formed (Figure 5). The first group consisted of the microregion of Paranavaí, the second included Umuarama and Assaí, the third consisted of Astorga, Floraí, and Londrina, and the fourth group included Porecatu, Apucarana, Cornélio Procópio, and Cerro Azul.

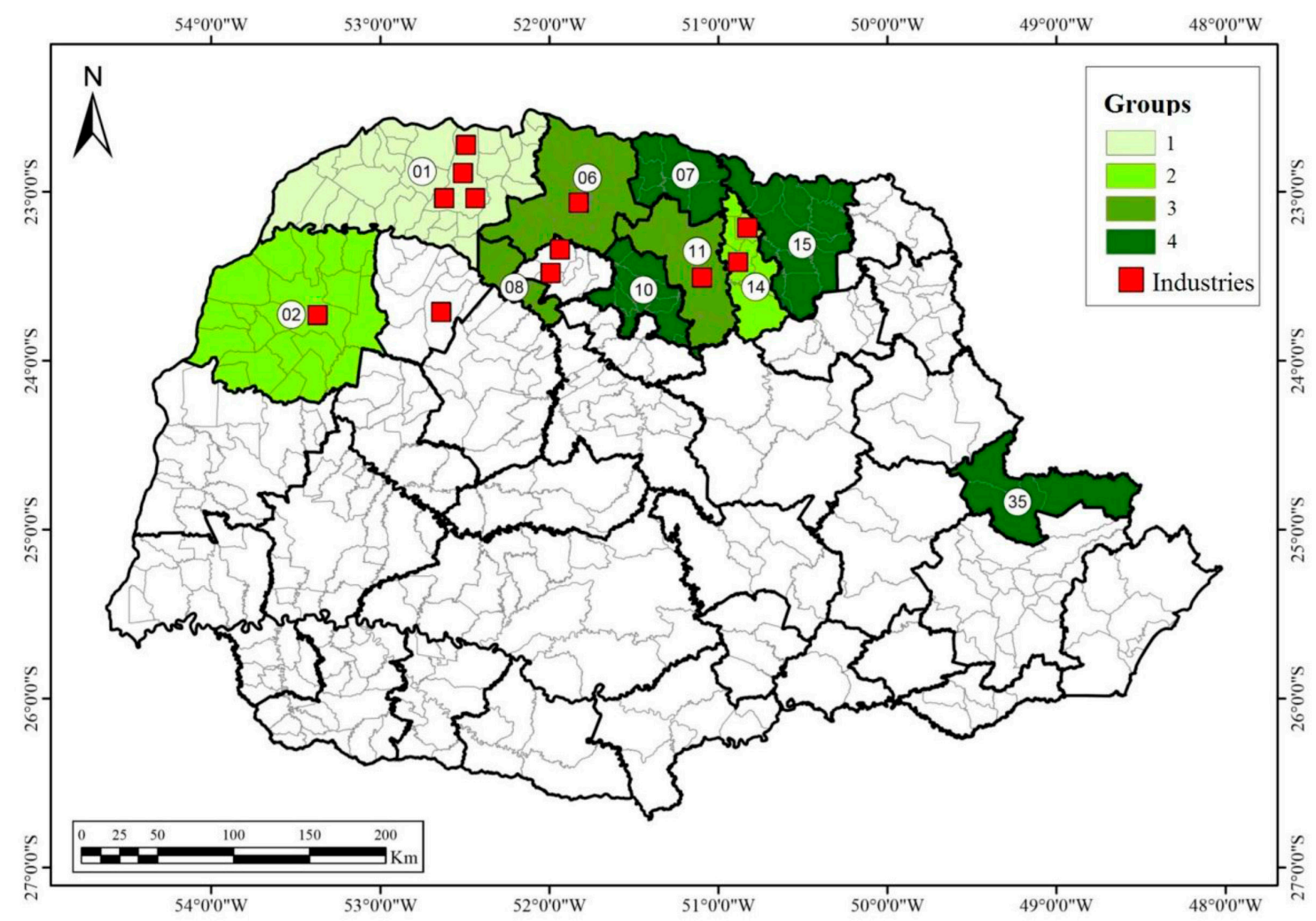

Figure 5. Cluster analysis of microregions specialized in orange production and location of industrial orange juice processing plants in Paraná; average data from 2013 to 2017.

Notes: 01: Paranavaí. 02: Umuarama. 06: Astorga. 07: Porecatu. 08: Floraí. 10: Apucarana. 11: Londrina. 14: Assaí. 15: Cornélio Procópio. 35: Cerro Azul.

Group 1 was represented by the microregion of Paranavaí, which used high technology that was related to the high average orange productivity index, which was the highest in Paraná. Another characteristic of this group was that $79.3 \%$ of the total CSV and $38.4 \%$ of the total PRONAMP, which were funding sources for medium and large producers, were concentrated in the microregion of Paranavaí. In addition, four large orange juice processing industries in Paraná were concentrated in this microregion.

Group 2 was characterized by many family production units and little use of technology; it was represented by the microregions of Assaí and Umuarama. These microregions received $57.94 \%$ of the total PRONAF, $5.7 \%$ of the PRONAMP, and $9.9 \%$ of the CSV. Despite consisting of microregions with low technification levels (their productivity was below $30 \mathrm{t} \mathrm{ha}^{-1}$ ), this group included three orange juice processing industries, two of which were located in the microregion of Assaí and one in Umuarama.
Group 3 was composed of the microregions of Astorga, Floraí, and Londrina. It was characterized by high technification as it had two orange juice processing industries and only a few family production units, while it included mainly medium-sized producers. This group received $55.9 \%$ of the total PRONAMP, $7.4 \%$ of the CSV, and $3.7 \%$ of the PRONAF.

Group 4, which was composed of the microregions of Porecatu, Apucarana, Cornélio Procópio, and Cerro Azul, was characterized by low technification and by an absence of orange processing industries, while it received little rural credit. Only $11.3 \%$ and $3.4 \%$ of the total PRONAF and CSV, respectively, were allocated to these microregions.

Industries and agribusiness cooperatives linked to orange production in Paraná were concentrated in specialized microregions, especially in the northwestern and mid-northern Paraná (Table 3). 
Table 3. Location of industrial orange juice processing plants in the state of Paraná.

\begin{tabular}{lcc}
\hline Company/Industry & Municipality & Microregion \\
\hline Nosliw & Assaí & Assaí \\
Cooperativa Integrada & Uraí & Assaí \\
McGrif do Brasil & Santa Fé & Astorga \\
Orangito & Cianorte & Cianorte \\
Sucos Natú & Londrina & Londrina \\
Cocamar - Purity & Maringá & Maringá \\
Cooper Sucos e Polpas & Maringá & Maringá \\
Suco Prat's & Paranavaí & Paranavaí \\
Ice Citrus & Paranavaí & Paranavaí \\
Dreyfus & Paranavaí & Paranavaí \\
Citri & Paranavaí & Paranavaí \\
Viva Feliz & Umuarama & Umuarama \\
\hline
\end{tabular}

Note: Survey carried out in June 2018.

The spatial concentration of industries in the citrus sector can be understood as the dynamics of the domain in terms of a certain economic activity practiced by large companies and industries (FEIJO et al., 2003). More industries were located in the municipality of Paranavaí, considering that this location has four of the 12 orange juice processing industries in Paraná (Table 3). The concentration of industrial plants or agribusiness cooperatives for the processing of orange juice provides economic development to a given region as it generates jobs and, consequently, increases the income and the consumption. It also enables social development, which, according to Rodrigues and Simões (2004), represents the consolidation of basic policies for economic activity by directing resources to education, health, and the environment. Furthermore, the economic development of these regions is closely linked to job generation. Such development in these regions allows autonomy in decision-making, increases the ability to obtain and reinvest the generated profits, and establishes a dynamic of social inclusion and territorial confluence based on industrial growth (HADDAD, 2009).

\section{Conclusions}

Orange production for industrial purposes was concentrated in the northern and northwestern regions of Paraná.

The number of microregions specialized in orange production expanded from nine in the 1998-2002 period to 10 in the 2013-2017 period.

The microregion of Paranavaí stood out in terms of orange production in Paraná, both due to its high technification, evidenced by its high productivity index, and due to the large harvested area and amount of oranges produced.
The dynamics of orange production in Paraná were spatially associated with the location of industries and agribusiness cooperatives in the sector.

\section{Acknowledgments}

To the Fundo Paraná from the Superintendência Geral de Ciência, Tecnologia e Ensino Superior do Paraná for their financial support.

\section{References}

AULER, P.A.M.; FIDALSKI, J.; PAVAN, M.A.; NEVES, C.S.V.J. Produção de laranja "Pêra" em sistemas de preparo de solo e manejo nas entrelinhas. Revista Brasileira de Ciência do Solo, Viçosa, MG, v.32, n.1, p.363-374, 2008.

AULER, P.A.M.; LEITE JUNIOR, R.P.; TAZIMA, Z.H.; ANDRADE, P.F.S. A citricultura no Paraná. Citricultura Atual, Cordeirópolis, v.17, n.99, p.17-20, 2014.

BCB. Banco Central do Brasil. Anuário estatístico do crédito rural. Brasilia, 2019. Disponível em: http://www. bcb.gov.br. Acesso em: 27 fev.2019.

FEIJO, C. A.; CARVALHO, P.G. M.; RODRIGUEZ, M. S. Concentração industrial e produtividade do trabalho na indústria de transformação nos anos 90: evidências empíricas. Economia, Niteroi, v.4, n.1, p.19-52, 2003

FRACASSO, A.; MARZETTI, G.V. Estimating dynamic localization economies: The inadvertent success of the specialization index and the location quotient. Regional Studies, Cambridge, v.52, n.1, p.119-132, 2017. 
FREITAS, R.E.; MENDONÇA, M.A.A. Expansão agrícola no Brasil e a participação da soja: 20 anos. Revista de Economia e Sociologia Rural, Brasília, DF, v.54, n.3, p.497-516, 2016.

FUKUDA, L.A.; FRANCO, D.; FACIO, S.L.; LIMA NETO, R.S. Sustentabilidade econômica da citricultura perante o huanglongbing. Citrus Research \& Technology, Cordeirópolis, v.31, n.2, p.107-114, 2010.

GASQUES, J.G. Sources of growth in Brazilian agriculture: Total factor productivity. EuroChoices, Oxford, v.16, n.1, p.24-25, 2017.

HADDAD, P.R. Capitais intangíveis e desenvolvimento regional. Revista de Economia, Curitiba, v.35, n.3, p.119146, 2009.

IAPAR - Instituto Agronômico do Paraná. Regionalização da citricultura para o estado do Paraná. Londrina, 1987. (Circular, 55).

IBGE - Instituto Brasileiro de Geografia e Estatística. Pesquisa Agrícola Municipal - PAM. Rio de Janeiro, 2019. Disponível em: https://sidra.ibge.gov.br. Acesso em: 27 fev.2019.

ISSERMAN, A. The location quotient approach to estimating regional economics impacts. Journal of the American Planning Association, Chicago, v.43, n.1, p.33-41, 1977.

LEITE JUNIOR, R. P.; MOHAN, S. K. Integrate management of the citrus bacterial cancker disease caused by Xanthomonas campestris pv.citri in the State of Paraná. Crop Protection, Guildford, v.9, p.3-7, 1990.

MARION FILHO, P.J.; MOURA, A.C.; BRITES, M.; LORENZONI, R.K. Concentração regional e especialização na produção de leite do Rio Grande do Sul (1990-2010). Revista Brasileira de Gestão e Desenvolvimento Regional, Taubaté, v.11, n.1, p.224242, 2015.

MODA-CIRINO, V.; GERAGE, A.C.; RIEDE, C.R.; SERA, G.H.; TAKAHASHI, M.; ABBUD, N.S.; NAZARENO, N.R.X.; ARAÚJO, P.M.; AULER, P.M.; YAMAOKA, R.S.; SERA, T.; ALMEIDA, W.P. Plant breeding at Instituto Agronômico do Paraná: IAPAR. Crop Breeding and Applied Biotechnology, Viçosa, MG, v.12, p.25-30, 2012.
MOREIRA, A.S.; STUCHI, E.S.; SILVA, P.R.B.; BASSANEZI, R.B.; GIRARDI, E.A.; LARANJEIRA, F.F.Could tree density play a role in managing Citrus Huanglongbing epidemics? Tropical Plant Pathology, Brasília, DF, v.44, n.3, p.268-274, 2019.

NEVES, M.F.; KALAKI, R.B. Citricultura: Perspectivas para a produção brasileira. Agroanalysis, Rio de Janeiro, v.35, n.6, p.26-27, 2015.

RODRIGUES, C.G.; SIMÕES, R. Aglomerados industriais e desenvolvimento socioeconômico: Uma análise multivariada para Minas Gerais. Ensaios FEE, Porto Alegre, v.25, n.1, p.203-232, 2004.

SABES, J.J.S.; SOUZA FILHO, H.M.S. Análise da influência dos principais aspectos do ambiente institucional para o desempenho competitivo do agrossistema da laranja do estado do Paraná. Revista em Agronegócios e Meio Ambiente, Maringá, v.3, n.2, 2010.

TAZIMA, Z.H; NEVES, C.S.V.J.; STENZEL, N.M.C.; YADA, I.F.U.; LEITE JUNIOR, R.P. Produção e qualidade de frutas de cultivares de laranja-doce no norte do Paraná. Revista Brasileira de Fruticultura, Jaboticabal, v.31, n.2, p.474-479, 2009.

TAZIMA, Z.H.; AULER, P.A.M.; NEVES, C.S.V.J.; YADA, I.F.U.; JUNIOR, R.P.L. Comportamento de clones de laranja 'valência' na região norte do Paraná. Revista Brasileira de Fruticultura, Jaboticabal, v.30, n.4, p.970974, 2008.

TAZIMA, Z. H.; NEVES, C. S. V.J.; YADA, I. F. U.; LEITE JÚNIOR, R. P.Produção e qualidade dos frutos de clones de laranjeira-'Pera' no norte do Paraná. Revista Brasileira de Fruticultura, Jaboticabal, v.32, n. 1, p.189195, 2010.

TELLES, T.S.; BACCHI, M.D.; SHIMIZU, J. Spatial distribution of microregions specialized in milk production. Semina: Ciências Agrárias, Londrina, v.38, n.1, p.443454, 2017.

USDA - United States Department of Agriculture. Citrus: world markets and trade. Disponível em: https://www.fas. usda.gov. Acesso em: 21 set. 2019.

VIEIRA FILHO, J.E.R. Brazilian agriculture innovation and production distribution. Revista de Política Agrícola, Brasília, DF, v.27, n.2, p.18-30, 2018. 
VARGAS, R.G.; GONÇALVES-ZULIANI, A.M.O.; CROCE FILHO, J.; CARVALHO, S.A.; NOCCHI, P.T.R.; NUNES, W.M.C. Avaliação da resistência de variedades de Citrus spp.à Xanthomonas citri subsp.citri na região Noroeste Paranaense, em condições de campo. Summa Phytopathologica, Botucatu, v. 39, n. 4, 235-241, 2013.
VOLSI, B.; TELLES, T.S.; CALDARELLI, C.E.; CAMARA, M.R.G. The dynamics of coffee production in Brazil. PLoS One, San Francisco, v.14, p.e0219742, 2019. 
Rev. Bras. Frutic., Jaboticabal, 2020, v. 42, n. 2: (e-525) 